\title{
Response of canola to row configuration, humic acid and sulphur application
}

\author{
Syed Awais Ahmad ${ }^{1}$, Amanullah Jan ${ }^{1}$, Habib Akbar ${ }^{1}$, Akhtar Ali $^{1 *}$, \\ Mohammad Wasiullah Khan ${ }^{2}$, Wazir Rehan ${ }^{3}$, Ata Ur Rahman ${ }^{1}$ and \\ Kabir Khan ${ }^{1}$ \\ 1. Department of Agronomy, The University of Agriculture Peshawar-Pakistan \\ 2. Department of Horticulture, The University of Agriculture Peshawar-Pakistan \\ 3. Directorate Agriculture Research Institute Tarnab, Peshawar-Pakistan \\ *Corresponding author's email: akhtarali@aup.edu.pk \\ Citation
}

Syed Awais Ahmad, Amanullah Jan, Habib Akbar, Akhtar Ali, Mohammad Wasiullah Khan, Wazir Rehan, Ata Ur Rahman and Kabir Khan. Response of canola to row configuration, humic acid and sulphur application. Pure and Applied Biology. Vol. 8, Issue 1, pp256-270. http://dx.doi.org/10.19045/bspab.2018.700184

\begin{tabular}{llll}
\hline Received: 08/08/2018 & Revised: 29/10/2018 & Accepted: 02/11/2018 & Online First: 05/11/2018
\end{tabular}

\section{Abstract}

According to the increasing demand of edible oil, an experiment was conducted in order to evaluate the response of canola to row configuration, humic acid and sulfur application at Agronomy Research Farm, The University of Agriculture Peshawar, during Rabi season 2015-2016. The experiment was laid out in RCB design replicated three times. The plot size was $14.4 \mathrm{~m}^{-2}$ having 12 rows, $40 \mathrm{~cm}$ apart. The experiment was consisted of three row configurations (solid rows), 3 solid rows +1 skipped row (3:1 ratio), 2 solid rows +1 skipped row (2:1 ratio), having two humic acid levels $\left(0\right.$ and $\left.4 \mathrm{~kg} \mathrm{ha}^{1}\right)$ and four sulfur levels $\left(0,15,30,45 \mathrm{~kg} \mathrm{ha}^{-1}\right)$. Crop growth rate $(5.1 \mathrm{~g}$ $\left.\mathrm{m}^{-2} \mathrm{~d}^{1}\right)$, number of grains pod $^{-1}(22)$, grain yield $\left(1657 \mathrm{~kg} \mathrm{ha}^{-1}\right)$, oil yield $\left(749 \mathrm{~kg} \mathrm{ha}^{-1}\right)$, oil content (45.2\%), glucosinolate content (14.8 u mol g-1) and erucic acid (1.7\%) were significantly higher with 2:1 ratio. Sulphur at the rate of $45 \mathrm{~kg} \mathrm{ha}^{-1}$ had significantly high number of seeds pod ${ }^{-1}(23)$, 1000 -grain weight $(4.5 \mathrm{~g})$, grain yield $\left(1790 \mathrm{~kg} \mathrm{ha}^{-1}\right)$, oil yield $\left(809 \mathrm{~kg} \mathrm{ha}^{-1}\right)$, oil content (45\%), glucosinolate content $\left(19.3 \mathrm{u} \mathrm{mol} \mathrm{g}^{-1}\right)$ and erucic acid (1.9\%), while sulphur at the rate of $30 \mathrm{~kg}$ $\mathrm{ha}^{-1}$ significantly increased crop growth rate $\left(5.1 \mathrm{~g} \mathrm{~m}^{-2} \mathrm{~d}^{-1}\right)$. Sulphur at the rate of $45 \mathrm{~kg} \mathrm{ha}^{-1}$, having row configuration of 2 solid row +1 skipped row are recommended for higher seed yield, oil yield and oil content of canola at Peshawar valley.

Keywords: Growth; Oil quality; Yield etc.

\section{Introduction}

Rapeseed (Brassica napus L.) is one of the most important oil crops in the world [1]. Rapeseed is a prominent member of family Cruciferae and genus Brassica [2]. Rapeseed was grown in the Indus Valley at about 300 $\mathrm{BC}$ as a feed for animals and its oil was used for shining the lamps and as food additive only by the poors $[2,3]$. They are famous for its oil purpose but the erucic acid and glucosinolate present in its oil and seed cake renders it unfit for human and animals as well. Due to the presence of these compounds, Brassica could not get important position among the oilseed crops until the introduction of canola in 1976 [4]. Erucic acid less than $2 \%$ in oil and glucosinolate amount less than $30 \mathrm{u} \mathrm{mol} \mathrm{g}^{-1}$ in cake are the 
permissible limits for meal [5]. Decreasing the amount of these chemical in Canadian synthesized rapeseed brought it to the $3^{\text {rd }}$ most vital edible oil of the world, preceded by soyabean and palm oil respectively [6]. In Pakistan traditional rapeseed are grown as oil seed crop in both irrigated and rainfed conditions on large areas in the four provinces of the country [7]. The average yield in Canada was $3200 \mathrm{~kg} \mathrm{ha}^{-1}$, European Union is $3500 \mathrm{~kg} \mathrm{ha}^{-1}$ while in Australia production was $2000 \mathrm{~kg}^{1} \mathrm{ha}^{1}$ [8]. The average yield of Pakistan is very low $\left(922 \mathrm{~kg} \mathrm{ha}^{-1}\right)$ as compared to other developed countries of the world [9]. In Khyber Pakhtunkhwa average yield is $452 \mathrm{~kg} \mathrm{ha}^{-1}$. In Pakistan total area under rapeseed and mustard is $0.238 \mathrm{~m}$ ha while in Khyber Pakhtunkhwa the crop was sown on $0.018 \mathrm{~m}$ ha. Pakistan's total production of rapeseed and mustard is $0.22 \mathrm{~m}$ tones [10] out of which 8500 tones is contributed by Khyber Pakhtunkhwa.

Beneficial impact of row configuration was observed on various farming related issues such as erosion control, adequate drainage and permit optimum use of rainfall and irrigation water [11]. It can also minimize the effects of water stress and improve the availability of soil water to crops, reduce risk pertaining to crop production and hence the growers can obtain better yield [12]. Row arrangement of beans crop was narrow $(0.30$ $\mathrm{m})$ and wider $(0.75 \mathrm{~m})$ and yield was significantly increased with $0.30 \mathrm{~m}$ row as compared with the conventional arrangement of rows [13]. Row configuration had little effect on weed biomass as compared with plant density and leaf area index while these parameters have been increased with twin row configuration but has little effect on maize yield as compared to plant density which has more effect on yield [14]. Humic acid is an item of organic matter and play the role of organic fertilizer related to productivity. It provides energy to soil microbes which are essential for recycling of nutrients and also activate the microbial function for providing the native microbes with a carbon source for food and hence stimulate their growth and activity [15]. It improves all the physical properties of soil such as water holding capacity, porosity, aeration, and reduce soil erosion. It has positive effects the chemical properties of soil by increasing the buffering properties of soil, possess high ion exchange capacity. It also plays a fundamental role in accelerating plant cell division, promote growth, and increase viability of seed germination [16]. Humic acid enhances the mechanism of NPK availability to crop [17]. It control soil-borne diseases, improving soil health, nutrient uptake by plants, mineral availability, fruit quality, increase crop yield, stimulate plant enzymes/hormones and improve soil fertility in addition to fact that it decrease toxic effect of salt from the soil [18]. Increasing level of humic acid enhanced yield and growth parameters such as growth rate and crop grain yield [19]. The sulphur requirement for canola is higher as compared with cereals. Canola has higher protein content and its high proportion of cysteine and methionine, demand to the larger sulphur application [20]. Sulfur application at the rate of $20,40,60 \mathrm{~kg}$ $\mathrm{ha}^{-1}$ for Brassica napus shows that plant height, number of branches plant ${ }^{-1}$, number of leaves plant ${ }^{-1}$ and seed yield were increased significantly with increasing $S$ level up to $40 \mathrm{~kg} \mathrm{ha}^{-1}$ [21]. Being a new edible oil seed crop, many aspects of its production knowledge need to be unveiled. Low yielding varieties, use of marginal lands having low fertility, non-judicial use of fertilizer, improper time of sowing and conventional methods of sowing are amongst the factors limiting its seed yield and oil content.

\section{Materials and methods}

A field experiment was conducted at Agronomy Research Farm, The University of Agricultural Peshawar, during Rabi season 2015-16 to find out the effect of row 
configuration, humic acid and sulfur application on canola. The experiment was laid out in randomized complete block design (RCBD) having three replications. Three rows configurations i.e. solid rows (12 rows plot $\left.^{-1}\right)$, solid to skip ratio 2:1 (8 solid rows and 4 skip rows) and solid to skip ratio 3:1(9 solid rows and 3 skip rows) were used. In case of $3: 1$ ratio three planted rows were followed by one skip row while in case of 2:1 two planted rows were followed by one skip row. Phosphorus was applied at the rate of $60 \mathrm{~kg}$ $\mathrm{ha}^{-1}$ in the form of SSP at sowing time. Nitrogen $(\mathrm{N})$ was applied at the rate of 120 $\mathrm{kg} \mathrm{ha}^{-1}$ from urea. Half of $\mathrm{N}$ was applied at the time of sowing while the remaining was applied with $1^{\text {st }}$ irrigation after subtracting the amount of $\mathrm{N}$ been supplied through ammonium sulphate. Sulphur was applied in the form of ammonium sulphate fertilizer at the time of sowing. Sulfur levels were 0, 15, 30 and $45 \mathrm{~kg} \mathrm{ha}^{-1}$. Humic acid (HA) was applied at the rate of $4 \mathrm{~kg} \mathrm{ha}^{-1}$ and one control (0 kg S). Humic acid (HA) was mixed with sand and then applied at the seed bed preparation/sowing time. The canola variety Abaseen-95 was sown at seed rate of $6 \mathrm{~kg} \mathrm{ha}^{-}$ , at row to row distance of $40 \mathrm{~cm}$, having a plot size of $4.8 \mathrm{~m} \times 3 \mathrm{~m}$. All other agronomic practices were carried out uniformly for all the experimental units throughout the growing period when required.

For crop growth rate (CGR) samples were collected at random from $0.5 \mathrm{~m}$ central row. These samples were oven dried at $70 \mathrm{C}^{0}$ for 72 hours to determine their dry weight at flower initiation stage, pod initiation stage and physiological maturity respectively of each plot. Plant growth rate was calculated using the following formula.

CGR $\left(\mathrm{g} \mathrm{m}^{-2} \mathrm{~d}^{-1}\right)=(\mathrm{W} 2-\mathrm{W} 1) /(\mathrm{T} 2-\mathrm{T} 1) \times$ $(1 / \mathrm{GA}), \mathrm{W} 1=$ Initial Weight, $\mathrm{W} 2=$ final Weight $\mathrm{T} 1=$ Initial date of sampling, $\mathrm{T} 2=$ Final date of sampling and GA = ground area. For total number of seeds per pod, ten pods were randomly selected from every plot for calculating the average number of seed grains $\operatorname{pod}^{-1}$. For this purpose, all the pods were threshed and the average grains were considered as number of seed pod ${ }^{-1}$. For 1000 seed weight after threshing the experimental crop, weight of thousand seed grains (g) was determined from three different seed lots in each and every plot with electronic balance. All the rows were harvested in each plot at physiological maturity stages for obtaining grain yield. The produce was dried, threshed and weighed. This bulk yield was then converted in to $\mathrm{kg} \mathrm{ha}^{-1}$ using the following formula. Seed yield $\left(\mathrm{kg} \mathrm{ha}^{-1}\right)$ $=\underline{\text { Seed yield of harvested area } \times 10000}$ $\mathrm{R}-\mathrm{R}$ distance $\mathrm{x}$ R-length $\mathrm{x}$ No. of rows Oil yield $\mathrm{kg} \mathrm{ha}^{-1}$ was calculated by the following formula. Oil yield $\left(\mathrm{kg} \mathrm{ha}^{-1}\right)$

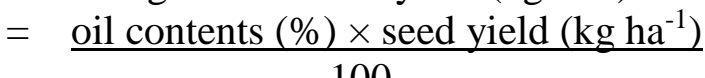
100

Glucosinolate and erucic acid content in the seed was determined by analyzing the samples obtained from bulk seed of each plot by FOSS Routine Near Infrared Analyzer (NIR) System (35RP-3752F), TR-3657-C Model 6500 at Oilseed Quality Laboratory., Crop Breeding Division, Nuclear Institute for Food and Agriculture (NIFA) Peshawar.

\section{Statistical analysis}

Data were subjected to analysis of variance (ANOVA) technique according to the methods suitable for RCB design [22] and means differences between treatments were compared by least significance difference at $5 \%$ level of probability when the F-test were significant.

\section{Results and discussion}

Crop growth rate $\left(\mathrm{g} \mathrm{m}^{-2} \mathrm{~d}^{-1}\right)$ of canola was influenced significantly (Table 1) by rows configuration and sulfur application and no effect of humic acid was observed for CGR. Maximum crop growth rate of $5.1 \mathrm{~g} \mathrm{~m}^{-2} \mathrm{~d}^{-1}$ was recorded at rows configuration of 2 solid +1 skipped row while minimum CGR ( $4.9 \mathrm{~g}$ $\mathrm{m}^{-2} \mathrm{~d}^{-1}$ ) were recorded at rows configuration at solid rows. Sulphur had significant effect 
crop growth as significantly higher CGR (5.1 $\mathrm{g} \mathrm{m}^{-2} \mathrm{~d}^{-1}$ ) was noted at $30 \mathrm{~kg} \mathrm{~S}^{-1}$ while lower CGR $\left(4.8 \mathrm{~g} \mathrm{~m}^{-2} \mathrm{~d}^{-1}\right)$ were obtained at 15 $\mathrm{kg} \mathrm{S} \mathrm{ha}^{-1}$. The control plots showed minimum crop growth rate $\left(4.7 \mathrm{~g} \mathrm{~m}^{-2} \mathrm{~d}^{-1}\right)$ as compare to treated plots while maximum crop growth rate $\left(5.2 \mathrm{~g} \mathrm{~m}^{-2} \mathrm{~d}^{-1}\right)$ were observed. All possible interactions were found nonsignificant. Application of $\mathrm{S}$ increases the crop growth and development [23] of canola significantly as compared to untreated plots. In similar fashion rows configuration had a positive effect $[24,25]$ on the crop growth rate of canola. Sulfur level and row configuration had significant effect on number of seed $\operatorname{pod}^{-1}$ (Table 2). More seed $\operatorname{pod}^{-1}(22)$ were noted at rows configuration of 2 solid row +1 skipped row while significantly lower number of seed $\operatorname{pod}^{-1}(21)$ were recorded at rows configuration at solid rows. Solid row had statistically similar response with 3 solid +1 skipped row. Humic acid had not significantly influenced the numbers of seed pod $^{-1}$. Maximum number of seed $\operatorname{pod}^{-1}(23)$ were recorded at $45 \mathrm{~kg} \mathrm{~S} \mathrm{ha}^{-1}$ whereas minimum (19) were recorded with $15 \mathrm{~kg} \mathrm{ha}{ }^{-1}$ and $30 \mathrm{~kg} \mathrm{~S} \mathrm{ha}{ }^{1}$ application. Control plots produced significantly lower number of seed pod $^{-1}$ (15) as compared with the treated ones (21) where it produced more seeds pod $^{-1}$. Seeds pod ${ }^{-1}$ revealed that rows configuration at 2 solid +1 skipped row (2:1) has significantly increased the number of seed pod $^{-1}$. Significant increase in number of seed pod $^{-1}$ were recorded [26] with rows configuration at 2:1. The effect of HA was non-significant, while sulfur applied at the rate of $45 \mathrm{~kg} \mathrm{ha}^{-1}$ significantly increase grains per pod of canola. More seeds pod ${ }^{-1}[27,28]$ of canola was produced in the plants treated with $45 \mathrm{~kg} \mathrm{~S} \mathrm{ha}^{-1}$. Similar results were obtained from a field trail on canola with the same parameters and treatments conducted by Imran et al. (2015). These findings are also supported by Megrath et al. (1999). Combine use of rows configuration and sulfur had significantly increased number of seed $\operatorname{pod}^{-1}$ [29]. Sulfur had significant effect (Table 3) on thousand grain weight. Rows configuration and humic acid had no effect on thousand seed weight of canola. Significantly higher seed weight ( $4.5 \mathrm{~g})$ was noted at $45 \mathrm{~kg} \mathrm{~S} \mathrm{ha}^{-1}$ while $30 \mathrm{~kg}$ and $15 \mathrm{~kg} \mathrm{~S}$ $\mathrm{ha}^{-1}$ statistically gave same response to seed weight (3.67 g) and (3.94 g) respectively. The control plots showed lower weight $(3.00 \mathrm{~g})$ for thousand grains as compared to the rest plots which gave maximum thousand seed weight (4.26 g). Increasing $S$ level up to 45 $\mathrm{kg} \mathrm{ha}^{-1}$ produced heavier seeds of canola as compared to untreated experimental units [27]. Mean values of data revealed that rows configuration, and sulphur application had significantly influenced seed yield (Table 4) of canola. The plot with rows configuration at 2 solid +1 skipped row produced significantly higher seed yield (1657 kg ha-1) as compared to those of solid rows and 3 solid +1 skipped row. Humic acid had no significant effect on grain yield of canola while sulphur had significantly increased grain yield. Significantly higher grain yield $\left(1790 \mathrm{~kg} \mathrm{ha}^{-1}\right)$ recovered from the plot received $45 \mathrm{~kg} \mathrm{~S} \mathrm{ha}^{-1}$. The plots treated with $30 \mathrm{~kg}$ and $15 \mathrm{~kg} \mathrm{~S} \mathrm{ha}^{-1}$ produced lower yield but were statistically at par with one another. Control plots showed less grain yield (1374) as compared with treated plot (1599 $\left.\mathrm{kg} \mathrm{ha}^{-1}\right)$. All possible interactions were found nonsignificant. Grain yield of canola crop increased [26] at 2:1 rows configuration. Sulphur has enhanced the grain yield of canola [27], as maximum grain yield was obtained from the plots that received sulphur at the rate of $45 \mathrm{~kg} \mathrm{ha}^{-1}$. Oil content (\%) of canola grains (Table 5) showed that rows configuration, humic acid levels and sulphur application had significant effect on the oil content of canola. Significantly more oil content $(45.2 \%)$ were recorded at 2 solid +1 skipped row (2:1) while lower oil content of $44.4 \%$ and were recorded at solid rows. The 
oil content of 3 solid +1 skipped row were at par with 2:1 ratio. Humic acid had no significant effect on the oil content of canola. In case of $\mathrm{S}$ application high oil content $(45 \%)$ was recorded from plot treated with 45 $\mathrm{kg} \mathrm{S} \mathrm{ha}{ }^{-1}$. Significantly lower oil content of $43.9 \%$ and $44.3 \%$ were recorded from plot treated with $15 \mathrm{~kg}$ and $30 \mathrm{~kg} \mathrm{~S} \mathrm{ha}{ }^{-1}$ respectively and were similar statistically. Control plot showed lower oil content (41.2\%) as compare to the rest plots which gave high oil content $45.9 \%$. The interaction of RC x S was significant. The combine use of row configuration and sulphur increase oil content up to $2: 1$ ratio and $45 \mathrm{~kg} \mathrm{ha}^{-1}$ thereafter decline occur, while the interaction were found non-significant. Oil content of canola increase with 2:1 rows configuration [30]. More oil yield was obtained from $S$ applied plots which was probably due to more S (45 kg ha-1) application [27].

Oil yield $\left(\mathrm{kg} \mathrm{ha}^{-1}\right)$ of canola seed were significantly influenced (Table 6) by row configuration and sulfur application. Significantly higher oil yield of $749 \mathrm{~kg} \mathrm{ha}^{-1}$ was noted at 2 solid +1 skipped row while lower oil yield $692 \mathrm{~kg} \mathrm{ha}^{-1}$ and $693 \mathrm{~kg} \mathrm{ha}^{-1}$ were recorded from the plots sown at solid rows and 3 solid +1 skipped row (3:1) and the difference between these two was not significant. Humic acid had not significantly affected oil yield of canola. Sulfur provide significantly higher oil yield $809 \mathrm{~kg} \mathrm{ha}^{-1}$ when applied at the rate of $45 \mathrm{~kg} \mathrm{ha}^{-1}$. Those treated with $30 \mathrm{~kg}$ and $15 \mathrm{~kg} \mathrm{~S}^{-1}$ produce lower yield and were at par with one another. Control plots produced significantly lower oil yield ( $\left.566 \mathrm{~kg} \mathrm{ha}^{-1}\right)$ as compared to $\left(734 \mathrm{~kg} \mathrm{ha}^{-}\right.$ $\left.{ }^{1}\right)$ treated plots. The interaction between RC $\mathrm{x} S$ was significant. The combine use of sulphur and row configuration demonstrating that canola crop had significantly improved oil yield up to $2: 1$ ratio and $45 \mathrm{~kg} \mathrm{ha}^{-1}$ then decline occur. Research revealed that increasing $\mathrm{S}$ application increased the oil yield of canola [26]. Row configuration and row skipping had a significant effect on the oil yield of canola [30]. Similar reports [33] showed that increasing $\mathrm{S}$ levels enhanced the oil yield of canola to the highest application. Glucosinolate content of canola (Table 7) obtained from 2 solid +1 skipped row (2:1) gave significantly higher glucosinolate concentration (14.8 u mol g $\mathrm{u}^{-1}$, while solid rows and 3 solid +1 skipped row gave lower glucosinolate concentration (13.1) and (14.0). The effect of humic acid was not significant on glucosinolate of canola. Sulphur had significantly affected glucosinolate concentration of canola. Higher glucosinolate concentration $\left(19.3 \mathrm{u} \mathrm{mol} \mathrm{g}^{-1}\right)$ was obtained at sulphur level of $45 \mathrm{~kg} \mathrm{ha}^{-1}$ while lower concentration of glucosinolate were obtained at $S$ level of $15 \mathrm{~kg} \mathrm{ha}^{-1}$ and 30 $\mathrm{kg} \mathrm{ha}^{-1}$ respectively but were statistically similar. Control plots resulted lower concentration of glucosinolate $\left(7.2 \mathrm{u} \mathrm{mol} \mathrm{g}^{-1}\right)$ while higher concentration of glucosinolate (14.0 $\mathrm{u} \mathrm{mo} \mathrm{g}^{-1}$ ) were recorded from the treated plots. The interactions were nonsignificant. Maximum glucosinolate content was recorded in [26] 2:1 rows configuration. Application of sulphur at the rate of $45 \mathrm{~kg} \mathrm{ha}$ 1 produced more glucosinolate content [27]. The increase in glucosinolate contents of canola with rising dose of sulphur might be due to the fact that glucosinolate is a sulphur containing complex, so when the application of $\mathrm{S}$ was enhanced glucosinolate contents were also increased $[31,33]$. Erucic acid (\%) was affected significantly (Table 8 ) by rows configuration, levels of humic acid and sulphur application. The rows configuration of 2 solid +1 skipped row gave significantly higher erucic acid of $(1.7 \%)$ while rows configuration at solid rows and 3 solid +1 skipped row showed minimum erucic acid and they were similar statistically. The humic acid has no significant impact on erucic acid content of canola. The plot receiving $45 \mathrm{~kg}$ $\mathrm{ha}^{-1} \mathrm{~S}$ produced significantly more erucic acid $(1.9 \%)$ as compared to those which were 
treated with $15(1.3 \%)$ and $30 \mathrm{~kg} \mathrm{~S} \mathrm{ha}^{-1}$ $(1.5 \%)$. The control plots showed lower erucic acid $(1.1 \%)$ as compare to the rest plots which gave more erucic acid (1.6\%). The interactions were not significant. Erucic acid increases with changing row configuration at 2:1 [26] which confirmed our findings. Sulphur application at the rate of $45 \mathrm{~kg} \mathrm{ha}^{-1}$ significantly enhanced the erucic acid percentage [32].

Table 1. Crop growth rate $\left(\mathrm{g} \mathrm{m}^{-2} \mathrm{~d}^{-1}\right)$ of canola as affected by row configuration, humic acid and sulfur application

\begin{tabular}{|c|c|c|c|c|}
\hline \multirow{2}{*}{ Sulphur $\left(\mathrm{kg} \mathrm{ha}^{-1}\right)$} & \multicolumn{3}{|c|}{ Growth Stages } & \\
\hline & Stage 1 & Stage 2 & Mean & \\
\hline 15 & 4.8 & 4.7 & 4.8 & $\mathrm{~b}$ \\
\hline 30 & 5.2 & 5.0 & 5.1 & $\bar{a}$ \\
\hline 45 & 4.9 & 5.1 & 5.0 & $\mathrm{c}$ \\
\hline LSD for Sulphur & & & 4.0 & \\
\hline \multicolumn{5}{|l|}{ Row configuration (RC) } \\
\hline Solid rows & 5.1 & 4.8 & 4.9 & $\mathrm{~b}$ \\
\hline 3 solid row +1 skipped row $(3: 1)$ & 4.8 & 4.9 & 4.9 & $\mathrm{~b}$ \\
\hline 2 solid row +1 skipped row $(2: 1)$ & 5.1 & 5.0 & 5.1 & $\mathrm{a}$ \\
\hline LSD for RC & & & 4.0 & \\
\hline \multicolumn{5}{|l|}{ Humic Acid (HA) $\left(\mathrm{kg} \mathrm{ha}^{-1}\right)$} \\
\hline 0 & 4.8 & 4.8 & 4.8 & \\
\hline 4 & 5.1 & 5.0 & 5.1 & \\
\hline LSD for HA & & & ns & \\
\hline \multicolumn{4}{|l|}{ Stages } & \\
\hline Stage 1 & & & 5.0 & \\
\hline Stage 2 & & & 4.9 & \\
\hline LSD for Stages & & & ns & \\
\hline Interactions & Sig Levels & Interactions & Sig Levels & \\
\hline $\mathrm{RC} \times \mathrm{S}$ & Ns & $\mathrm{STG} \times \mathrm{HA}$ & ns & \\
\hline $\mathrm{HA} \times \mathrm{S}$ & Ns & $\mathrm{STG} \times \mathrm{S} \times \mathrm{RC}$ & ns & \\
\hline $\mathrm{RC} \times \mathrm{HA}$ & Ns & $\mathrm{STG} \times \mathrm{S} \times \mathrm{HA}$ & $\mathrm{ns}$ & \\
\hline $\mathrm{RC} \times \mathrm{HA} \times \mathrm{S}$ & $\mathrm{Ns}$ & $\mathrm{STG} \times \mathrm{RC} \times \mathrm{HA}$ & $\mathrm{ns}$ & \\
\hline $\mathrm{STG} \times \mathrm{S}$ & $\mathrm{Ns}$ & $\mathrm{STG} \times \mathrm{S} \times \mathrm{RC} \times \mathrm{HA}$ & ns & \\
\hline STG $\times$ RC & Ns & & & \\
\hline \multicolumn{4}{|l|}{ Planned Mean Comparison } & \\
\hline Control & $4.8 \mathrm{~b}$ & & & \\
\hline Rest & $5.1 \mathrm{a}$ & & & \\
\hline
\end{tabular}

Mean of same category with different letters are significantly different at 5\% level probability using LSD 
Table 2. Number of seed pod $^{-1}$ of canola as affected by row configuration, humic acid and sulfur application

\begin{tabular}{|c|c|c|c|c|c|}
\hline \multirow[t]{2}{*}{ Row Configuration (RC) } & \multirow{2}{*}{$\frac{\text { HA }}{\left(\mathrm{kg} \mathrm{ha}^{-1}\right)}$} & \multicolumn{3}{|c|}{ S $\left(\mathrm{kg} \mathrm{ha}^{-1}\right)$} & \multirow[t]{2}{*}{ RC x HA } \\
\hline & & 15 & 30 & 45 & \\
\hline & & & $\mathrm{RC} \times \mathrm{HA} \times \mathrm{S}$ & & \\
\hline \multirow[t]{2}{*}{ Solid rows } & 0 & 24 & 18 & 22 & 21 \\
\hline & 4 & 24 & 22 & 23 & 23 \\
\hline \multirow[t]{2}{*}{3 solid row +1 skipped $(3: 1)$} & 0 & 18 & 17 & 22 & 19 \\
\hline & 4 & 15 & 20 & 26 & 20 \\
\hline \multirow[t]{6}{*}{2 solid row +1 skipped $(2: 1)$} & 0 & 17 & 22 & 25 & 21 \\
\hline & 4 & 17 & 22 & 23 & 21 \\
\hline & & & $\mathrm{HA} \times \mathrm{S}$ & & Mean \\
\hline & 0 & 19 & 19 & 23 & 20 \\
\hline & 4 & 19 & 21 & 23 & 21 \\
\hline & & & $\mathrm{RC} \times \mathrm{S}$ & & Mean \\
\hline Solid row & & 24 & 20 & 24 & $21 \mathrm{~b}$ \\
\hline 3 solid row +1 skipped $(3: 1)$ & & 16 & 19 & 23 & $20 \mathrm{~b}$ \\
\hline 2 solid row +1 skipped $(2: 1)$ & & 24 & 22 & 24 & $22 \mathrm{a}$ \\
\hline Mean & & $19 \mathrm{~b}$ & $20 \mathrm{ab}$ & $23 \mathrm{a}$ & \\
\hline \multicolumn{6}{|l|}{ Planned Mean Comparison } \\
\hline Control & $15 \mathrm{~b}$ & & & & \\
\hline Rest & $21 \mathrm{a}$ & & & & \\
\hline
\end{tabular}

LSD at $\mathrm{p} \leq 0.05$ for $\mathrm{S}=2.0$

LSD at $\mathrm{p} \leq 0.05$ for $\mathrm{RC}=2.0$

LSD at $\mathrm{p} \leq 0.05$ for $\mathrm{RC} \times \mathrm{S}=3$

Mean of same category with different letters are significantly different at $5 \%$ level probability using LSD

$\mathrm{HA}=$ Humic acid

$\mathrm{S}=$ Sulphur 
Table 3. Thousand seed weight (g) of canola as affected by row configuration, humic acid and sulphur application

\begin{tabular}{|c|c|c|c|c|c|}
\hline Row Configuration (RC) & HA & \multicolumn{3}{|c|}{ S $\left(\mathbf{k g ~ h a}^{-1}\right)$} & RC $\times$ HA \\
\hline & $\left(\mathrm{kg} \mathrm{h}^{-1}\right)$ & 15 & 30 & 45 & \\
\hline & & & $\mathrm{RC} \times \mathrm{HA} \times \mathrm{S}$ & & \\
\hline Solid rows & 0 & 3.67 & 4.67 & 4.00 & 4.11 \\
\hline & 4 & 4.67 & 3.67 & 4.67 & 4.33 \\
\hline 3 solid row + 1 skipped row (3:1) & 0 & 3.33 & 4.67 & 3.67 & 3.89 \\
\hline & 4 & 4.00 & 4.33 & 3.33 & 3.89 \\
\hline 2 solid row + 1 skipped row (2:1) & 0 & 4.00 & 4.00 & 3.00 & 3.66 \\
\hline & 4 & 4.67 & 4.00 & 3.33 & 4.00 \\
\hline & & & HA $\times \mathrm{S}$ & & Mean \\
\hline & 0 & 3.67 & 4.44 & 4.56 & 4.22 \\
\hline & 4 & 4.44 & 4.00 & 4.44 & 4.30 \\
\hline & & & $\mathrm{RC} \times \mathrm{S}$ & & Mean \\
\hline Solid rows & & 4.17 & 4.17 & 4.33 & 4.22 \\
\hline 3 solid row + 1 skipped row (3:1) & & 3.50 & 3.67 & 4.50 & 3.89 \\
\hline 2 solid row + 1 skipped row (2:1) & & 3.33 & 4.00 & 4.67 & 4.33 \\
\hline Mean & & $3.67 \mathrm{~b}$ & $3.94 \mathrm{~b}$ & $4.5 \mathrm{a}$ & \\
\hline Planned Mean Comparison & & & & & \\
\hline Control & $3.00 \mathrm{~b}$ & & & & \\
\hline Rest & $4.26 \mathrm{a}$ & & & & \\
\hline
\end{tabular}

LSD at $\mathrm{p} \leq 0.05$ for $\mathrm{S}=0.61$

Mean of same category with different letters are significantly different at $5 \%$ level probability using LSD.

$\mathrm{HA}=$ Humic acid

$\mathrm{S}=$ Sulphur 
Table 4. Seed yield $\left(\mathrm{kg} \mathrm{ha}^{-1}\right)$ of canola as affected by row configuration, humic acid and sulfur application

\begin{tabular}{|c|c|c|c|c|c|}
\hline \multirow[t]{2}{*}{ Row Configuration (RC) } & \multirow{2}{*}{$\frac{\text { HA }}{\left(\mathrm{kg} \mathrm{ha}^{-1}\right)}$} & \multicolumn{3}{|c|}{ S $\left(\mathrm{kg} \mathrm{ha}^{-1}\right)$} & \multirow[t]{2}{*}{$\mathbf{R C} \times \mathbf{H A}$} \\
\hline & & 15 & 30 & 45 & \\
\hline & & & $\mathrm{RC} \times \mathrm{HA} \times \mathrm{S}$ & & \\
\hline \multirow[t]{2}{*}{ Solid rows } & 0 & 1482 & 1430 & 1789 & 1570 \\
\hline & 4 & 1416 & 1419 & 1818 & 1551 \\
\hline \multirow[t]{2}{*}{3 solid row +1 skipped $(3: 1)$} & 0 & 1534 & 1471 & 1784 & 1596 \\
\hline & 4 & 1502 & 1443 & 1742 & 1563 \\
\hline \multirow[t]{6}{*}{2 solid row +1 skipped $(2: 1)$} & 0 & 1596 & 1502 & 1846 & 1648 \\
\hline & 4 & 1603 & 1645 & 1749 & 1666 \\
\hline & & & $\mathrm{HA} \times \mathrm{S}$ & & Mean \\
\hline & 0 & 1537 & 1468 & 1809 & 1605 \\
\hline & 4 & 1507 & 1502 & 1770 & 1593 \\
\hline & & & $\mathrm{RC} \times \mathrm{S}$ & & Mean \\
\hline Solid row & & 1449 & 1424 & 1808 & $1560 \mathrm{~b}$ \\
\hline 3 solid row +1 skipped $(3: 1)$ & & 1518 & 1457 & 1763 & $1579 \mathrm{~b}$ \\
\hline 2 solid row +1 skipped $(2: 1)$ & & 1600 & 1574 & 1798 & $1657 \mathrm{a}$ \\
\hline Mean & & $1522 \mathrm{~b}$ & $1485 \mathrm{~b}$ & $1790 \mathrm{a}$ & \\
\hline \multicolumn{6}{|l|}{ Planned Mean Comparison } \\
\hline Control & $1374 \mathrm{~b}$ & & & & \\
\hline Rest & $1599 \mathrm{a}$ & & & & \\
\hline
\end{tabular}

LSD at $\mathrm{p} \leq 0.05$ for $\mathrm{S}=83$

LSD at $\mathrm{p} \leq 0.05$ for $\mathrm{RC}=83$

Mean of same category with different letters are significantly different at $5 \%$ level probability using LSD.

HA= Humic acid

$\mathrm{S}=$ Sulphur 
Table 5. Oil content (\%) of canola as affected by row configuration, humic acid and sulfur application

\begin{tabular}{|c|c|c|c|c|c|}
\hline \multirow[t]{2}{*}{ Row Configuration (RC) } & \multirow{2}{*}{$\frac{\text { HA }}{\left(\mathrm{kg} \mathrm{ha}^{-1}\right)}$} & \multicolumn{3}{|c|}{$\mathrm{S}\left(\mathrm{kg} \mathrm{ha}^{-1}\right)$} & \multirow[t]{2}{*}{$\mathbf{R C} \times \mathbf{H A}$} \\
\hline & & 15 & 30 & 45 & \\
\hline & & & $\mathrm{RC} \times \mathrm{HA} \times \mathrm{S}$ & & \\
\hline \multirow[t]{2}{*}{ Solid rows } & 0 & 42.9 & 42.3 & 43.0 & 42.7 \\
\hline & 4 & 42.3 & 44.5 & 43.1 & 42.9 \\
\hline \multirow[t]{2}{*}{3 solid row +1 skipped row $(3: 1)$} & 0 & 44.3 & 44.0 & 45.6 & 44.6 \\
\hline & 4 & 43.1 & 45.6 & 44.3 & 44.3 \\
\hline \multirow[t]{6}{*}{2 solid row +1 skipped row $(2: 1)$} & 0 & 44.7 & 43.4 & 46.6 & 44.9 \\
\hline & 4 & 44.7 & 44.0 & 43.2 & 43.9 \\
\hline & & & $\mathrm{HA} \times \mathrm{S}$ & & Mean \\
\hline & 0 & 44.6 & 43.3 & 40.4 & 42.7 \\
\hline & 4 & 44.0 & 44.4 & 42.6 & 43.6 \\
\hline & & & $\mathrm{RC} \times \mathrm{S}$ & & Mean \\
\hline Solid rows & & 42.6 & 44.7 & 44.7 & $43.6 \mathrm{ab}$ \\
\hline 3 solid row + 1 skipped row $(3: 1)$ & & 44.9 & 43.7 & 43.7 & $44.4 \mathrm{~b}$ \\
\hline 2 solid row +1 skipped row $(2: 1)$ & & 45.6 & 43.4 & 46.7 & $45.2 \mathrm{a}$ \\
\hline Mean & & $44.3 \mathrm{ab}$ & $43.9 \mathrm{~b}$ & $45 \mathrm{a}$ & \\
\hline \multicolumn{6}{|l|}{ Planned Mean Comparison } \\
\hline Control & $41.2 \mathrm{~b}$ & & & & \\
\hline Rest & $45.9 \mathrm{a}$ & & & & \\
\hline
\end{tabular}

LSD at $\mathrm{p} \leq 0.05$ for $\mathrm{S}=1.30$

LSD at $\mathrm{p} \leq 0.05$ for $\mathrm{RC}=1.30$

LSD at $\mathrm{p} \leq 0.05$ for $\mathrm{RC} \times \mathrm{S}=2.25$

Mean of same category with different letters are significantly different at $5 \%$ level probability using LSD.

$\mathrm{HA}=$ Humic acid

$\mathrm{S}=$ Sulphur 
Table 6. Oil yield $\left(\mathrm{kg} \mathrm{ha}^{-1}\right)$ of canola as affected by row configuration, humic acid and sulphur application

\begin{tabular}{|c|c|c|c|c|c|}
\hline \multirow[t]{2}{*}{ Row Configuration (RC) } & \multirow{2}{*}{$\begin{array}{c}\text { HA } \\
\left(\mathrm{kg} \mathrm{ha}^{-1}\right)\end{array}$} & \multicolumn{3}{|c|}{ S $\left(\mathrm{kg} \mathrm{ha}^{-1}\right)$} & \multirow[t]{2}{*}{$\mathbf{R C} \times \mathbf{H A}$} \\
\hline & & 15 & 30 & 45 & \\
\hline & & & $\mathrm{RC} \times \mathrm{HA} \times \mathrm{S}$ & & \\
\hline \multirow[t]{2}{*}{ Solid rows } & 0 & 636 & 637 & 832 & 702 \\
\hline & 4 & 601 & 634 & 820 & 685 \\
\hline \multirow[t]{2}{*}{3 solid row +1 skipped row $(3: 1)$} & 0 & 649 & 638 & 785 & 691 \\
\hline & 4 & 649 & 635 & 797 & 694 \\
\hline \multirow[t]{6}{*}{2 solid row +1 skipped row $(2: 1)$} & 0 & 691 & 741 & 843 & 758 \\
\hline & 4 & 692 & 856 & 776 & 774 \\
\hline & & & $\mathrm{HA} \times \mathrm{S}$ & & Mean \\
\hline & 0 & 659 & 739 & 820 & 739 \\
\hline & 4 & 647 & 742 & 798 & 729 \\
\hline & & & $\mathrm{RC} \times \mathrm{S}$ & & Mean \\
\hline Solid rows & & 619 & 635 & 826 & $693 \mathrm{~b}$ \\
\hline 3 solid row +1 skipped row $(3: 1)$ & & 649 & 637 & 791 & $692 \mathrm{~b}$ \\
\hline 2 solid row + 1 skipped row $(2: 1)$ & & 691 & 748 & 809 & $749 \mathrm{a}$ \\
\hline Mean & & $653 \mathrm{~b}$ & $673 \mathrm{~b}$ & $809 \mathrm{a}$ & \\
\hline \multicolumn{6}{|l|}{ Planned Mean Comparison } \\
\hline Control & $566 \mathrm{~b}$ & & & & \\
\hline Rest & $734 \mathrm{a}$ & & & & \\
\hline
\end{tabular}

LSD at $\mathrm{p} \leq 0.05$ for $\mathrm{S}=45$

LSD at $\mathrm{p} \leq 0.05$ for $\mathrm{RC}=45$

LSD at $\mathrm{p} \leq 0.05$ for $\mathrm{RC} \times \mathrm{S}=77$

Mean of same category with different letters are significantly different at $5 \%$ level probability using LSD.

$\mathrm{HA}=$ Humic acid

$\mathrm{S}=$ Sulphur 
Table 7. Glucosinolate content ( $\mathrm{u} \mathrm{mol} \mathrm{g}^{-1}$ ) of canola as affected by row configuration, humic acid and sulphur application

\begin{tabular}{|c|c|c|c|c|c|}
\hline Row Configuration (RC) & HA & \multicolumn{3}{|c|}{ S $\left(\mathbf{k g ~ h a}^{-1}\right)$} & RC $\times$ HA \\
\hline & $\left(\mathrm{kg} \mathrm{ha}^{-1}\right)$ & 15 & 30 & 45 & \\
\hline & & & $\mathrm{RC} \times \mathrm{HA} \times \mathrm{S}$ & & \\
\hline Solid rows & 0 & 7.2 & 13.1 & 17.4 & 12.6 \\
\hline \multirow{2}{*}{ 3 solid row + 1 skipped row (3:1) } & 4 & 9.1 & 12.6 & 19.0 & 13.5 \\
\cline { 2 - 6 } & 0 & 7.8 & 10.2 & 20.9 & 13.0 \\
\hline & 4 & 11.6 & 14.0 & 19.6 & 15.1 \\
\hline 2 solid row + 1 skipped row (2:1) & 0 & 12.0 & 13.7 & 18.8 & 14.8 \\
\hline & 4 & 11.7 & 12.6 & 20.1 & 14.8 \\
\hline & & & $\mathrm{HA} \times \mathrm{S}$ & & Mean \\
\hline & 0 & 9.0 & 12.3 & 19.0 & 13.5 \\
\hline & 4 & 10.8 & 13.0 & 19.6 & 14.5 \\
\hline & & & $\mathrm{RC} \times \mathrm{S}$ & & Mean \\
\hline Solid rows & & 8.2 & 12.8 & 18.2 & $13.1 \mathrm{~b}$ \\
\hline 3 solid row + 1 skipped row (3:1) & & 9.7 & 12.1 & 20.3 & $14.0 \mathrm{~b}$ \\
\hline 2 solid row + 1 skipped row (2:1) & & 11.9 & 13.2 & 19.5 & $14.8 \mathrm{a}$ \\
\hline Mean & & $9.9 \mathrm{~b}$ & $12.7 \mathrm{~b}$ & $19.3 \mathrm{a}$ & \\
\hline Planned Mean Comparison & & & & & \\
\hline Control & $7.2 \mathrm{~b}$ & & & & \\
\hline Rest & $14.0 \mathrm{a}$ & & & & \\
\hline
\end{tabular}

LSD at $\mathrm{p} \leq 0.05$ for $\mathrm{S}=1.43$

LSD at $\mathrm{p} \leq 0.05$ for $\mathrm{RC}=1.43$

Mean of same category with different letters are significantly different at $5 \%$ level probability using LSD.

$\mathrm{HA}=$ Humic acid

$\mathrm{S}=$ Sulphur 
Table 8. Erucic acid (\%) of canola as affected by row configuration, humic acid and sulfur application

\begin{tabular}{|c|c|c|c|c|c|}
\hline \multirow[t]{2}{*}{ Row Configuration (RC) } & \multirow{2}{*}{$\frac{\text { HA }}{\left(\mathrm{kg} \mathrm{ha}^{-1}\right)}$} & \multicolumn{3}{|c|}{ S $\left(\mathrm{kg} \mathrm{ha}^{-1}\right)$} & \multirow[t]{2}{*}{$\mathbf{R C} \times \mathbf{H A}$} \\
\hline & & 15 & 30 & 45 & \\
\hline & & & $\mathrm{RC} \times \mathrm{HA} \times \mathrm{S}$ & & \\
\hline Solid rows & 0 & 1.3 & 1.4 & 1.9 & 1.5 \\
\hline \multirow{3}{*}{3 solid row +1 skipped row $(3: 1)$} & 4 & 1.1 & 1.4 & 1.9 & 1.5 \\
\hline & 0 & 1.3 & 1.5 & 1.0 & 1.2 \\
\hline & 4 & 1.3 & 1.4 & 1.8 & 1.5 \\
\hline \multirow[t]{6}{*}{2 solid row +1 skipped row $(2: 1)$} & 0 & 1.4 & 1.5 & 1.1 & 1.3 \\
\hline & 4 & 1.3 & 1.0 & 1.8 & 1.7 \\
\hline & & & $\mathrm{HA} \times \mathrm{S}$ & & Mean \\
\hline & 0 & 1.3 & 1.5 & 1.0 & 1.2 \\
\hline & 4 & 1.2 & 1.6 & 1.8 & 1.6 \\
\hline & & & $\mathrm{RC} \times \mathrm{S}$ & & Mean \\
\hline Solid rows & & 1.2 & 1.4 & 1.9 & $1.5 \mathrm{~b}$ \\
\hline 3 solid row + 1 skipped row (3:1) & & 1.3 & 1.5 & 1.9 & $1.6 \mathrm{~b}$ \\
\hline 2 solid row +1 skipped row $(2: 1)$ & & 1.4 & 1.8 & 1.9 & $1.7 \mathrm{a}$ \\
\hline Mean & & $1.3 \mathrm{~b}$ & $1.5 \mathrm{~b}$ & $1.9 \mathrm{a}$ & \\
\hline \multicolumn{6}{|l|}{ Planned Mean Comparison } \\
\hline Control & $1.1 \mathrm{~b}$ & & & & \\
\hline Rest & $1.6 \mathrm{a}$ & & & & \\
\hline
\end{tabular}

LSD at $\mathrm{p} \leq 0.05$ for $\mathrm{S}=0.14$

LSD at $\mathrm{p} \leq 0.05$ for $\mathrm{RC}=0.14$

Mean of same category with different letters are significantly different at $5 \%$ level probability using LSD.

$\mathrm{HA}=$ Humic acid

$\mathrm{S}=$ Sulphur

\section{Conclusions}

Use of sulphur at the rate of $45\left(\mathrm{~kg} \mathrm{ha}^{-1}\right)$ gave higher seed yield as well as more oil yield and oil content of canola seeds. In case of row configuration of 2 solid +1 skipped row had significantly enhanced seed yield, oil yield and oil content of canola. Humic acid had not significantly affected growth and yield of canola while sulphur at the level of $45 \mathrm{~kg} \mathrm{ha}$ ${ }^{1}$ having row configuration of 2 solid +1 skipped row $(2: 1)$ is recommended for maximum grain, oil yield and oil content of canola in Peshawar.

\section{Authors' contributions}

Conceived and designed the experiments: SA Ahmad \& A Jan, Performed the experiments: SA Ahmad, Analyzed the data: A Ali, AA Khan \& AU Rahman, Contributed reagents/ materials/ analysis tools: H Akbar, W Rehan \& MW Khan, Wrote the paper: A Ali. 


\section{References}

1. Taheri E, Soleymani A \& Javanmard HR (2012).The effect of different Nitrogen Levels on oil yield and harvest index of two spring rapeseed cultivars in Isfahan region. Inter J Agric \& Crop Sci 4(20): 1496-1498.

2. Valizadeh N \& Mirshekari B (2011). Determination of economical yield loss threshold of Chenopodium album at interference with rapeseed (Brassica napus L). J Food Agric and Environ 9(2): 409-412.

3. Ma BL \& Herath AW (2016). Timing and rates of nitrogen fertiliser application on seed yield, quality and nitrogen-use efficiency of canola Crop and Pasture. Sci 67(2): 167-180.

4. Ghanbari-Malidarreh A (2010). Effects of nitrogen rates and splitting on oil contentand seed yield of canola (Brassica napus L.). American-Eurasian J Agric \& Environ Sci 8(2): 161-166.

5. Grant $\mathrm{C}, \mathrm{Wu} \mathrm{R}$, Selles F, Harker KN, Clayton GW, Bittman S, Zebarth BJ \& Lupwayi NZ (2012). Crop yield and nitrogen concentration with controlled release urea and split applications of nitrogen as compared to non-coated urea applied at seeding. Field Crops Res 127: 170180.

6. Canola Council of Canada (2013). Plant nutrition.

Available

at: www.canolacouncil.org/canola encyclopedia/crop-nutrition (accessed 4 November 2015).

7. Khan, AH, Khalil IA \& Shah H (2004). Nutritional yield and oil quality of canola cultivars grown in KPK. Sarhad J Agric 20(2): 287-290.

8. Reddy SR (2004). Principles of Crop Production. $2^{\text {nd }}$ Ed. Kalyani Publishers, New Delhi, India pp 46.

9. MNFSR (2013). Ministry for National Food Security and Research, Agric.
Statistics of Pakistan .Govt. of Pak, Economic Wing, Islamabad.

10. Pakistan oilseed development board (2016). Pakistan bureau of statistics, economic wing Islamabad.

11. Sattar A, Cheema MA, Wahid MA, Saleem MF \& Hassan M (2011). Interactive effect of sulphur and nitrogen on growth, yield and quality of canola. Crop Environ 2(1): 32-37.

12. Uzun B, Yol E \& Furat S (2012). The influence of row and intra-row spacing to seed yield and its components of winter sowing canola in the true Mediterranean type environment. Bulg $J$ Agric Sci 18: 83-91.

13. Ndung UKW, Kwambai TK, Bartutwo J, Omollo P, Kamid M \& Mulati J (2005). Effect of maize and bean spatial arrangement on bean yield in North Rift Kenya. African Crop Sci J 7: 1211-1215.

14. Balkcam SK, Satterwhite JL, Arriaga FJ, Price AJ \& Santen EV (2011). Conventional and glyphosate - resistant maize yield across plant densities in single -and twin row configuration. Field Crop Res J 120: 330-337.

15. Aisha H, Ali M, Shafeek R, Asmaaand MR \& Desuki MEl (2014). Effect of various levels of organic fertilizer and humic acid on the growth and root quality of (Brassica rape L.). Current Sci Int J 3(1): 7-14.

16. Gwathmey (2005). Humic acid works with fertilizers and micronutrients to produce better crops. Better crops 89(3): 6-10.

17. Khan R, Rashid A, Khan MS \& Ozturk E (2010). Impact of humic acid and chemical fertilizer application on growth and grain yield of rainfed wheat (Triticum aestivum L.). Pak J Agric Res 23(3-4): 113-121.

18. Rajpar M, Bhatti B, Hassan ZU, Shahand AN \& Tunio SD (2011). Humic acid improves growth, yield and oil content of 
(Brassica compestris L.). Pak J Agri 27(2): 125-133.

19. Nithila, S, Annaduri K, Jeyakumar P, Puppalaand N \& Angadi S (2013). Humic acid effect on growth yield and biochemical properties of field crops with particular reference to peanut. American J Agron 3: 530-532.

20. Sharifi RS (2012). Sulphur fertilizer effects on grain yield and the sum of physiological indices of canola (Brassica napus L.). Ann Bio Res 3(11): 65-67.

21. Shilpi S, Islam MN, Sutradhar GNC, Husnaand A \& Akter F (2013). Effect of nitrogen and sulphur on the growth and yield of canola (Brassica rape L.). Inter J Biores Stress Manag 3(2): 177-182.

22. Steel RGD \& Torri JH (1980). Principles and procedures of statistics, $2^{\text {hd }} \mathrm{Ed}$. Mcgraw hill book company lnc. New York.

23. Jamal A, Fazli IS, Ahmad S, Abdin MZ $\&$ Yun SJ (2005). Effect of S and N application on growth characteristics, seed and oil yield of canola. Korean $J$ Crop Sci 50(5): 340-345.

24. Begum F, Hussain F \& Mondal MRI (2012). Influence of Sulphur and row configuration on morpho- physiological and yield parameters of rape seed (Brassica compestris L.) Bangla J Agri Res 37(4): 645-652.

25. Maqbool MM, Tanveer A \& Ata Z (2007). Growth and yield of canola as affected by row configuration and nitrogen fertilization. Pak J Bot 38(4): 1227-1236.

26. Shahin Y \& Valiollah R (2009). Effect of row configuration and seeding rates on some agronomical traits of spring canola (Brassica napus L.) cultivars. J Cent Eur Agric 10(1): 112-115.

27. Imran, Khan AA, Inamullah, Zada $H$, Ahmad F, Shah ST, Usman A \& Irfanullah (2015). Yield and yield attributes of rapeseed cultivars as influence by sulphur level under swat valley conditions. Pure Appl Biol 4(3): 296-301.

28. Mcgrath SP \& Zhao FJ (1999). Sulphur uptake, yield response and the interactions between nitrogen and sulphur in winter oil seed rape. J Agri Sci 126(1): 53-62.

29. Cheema MA, Saleem M \& Malik MA (2001). Effect of row configuration and Sulphur fertilization on agronomic traits and oil quality of canola. Pak Agri Sci 41: 10-15.

30. Saleem M, Cheema MA \& Malik MA (2001). Agro- economic assessment of canola planted under different levels of nitrogen and row configuration. Inter $J$ Agric Bio 3(1): 27-30.

31. Mailer RJ (1989). Effect of applied sulphur on glucosinolate and oil concentration in the seeds of rape (Brassica rape L.) Aust J Agric Res 40: 617-624.

32. Ray K, Sengupta K, Pal AK \& Banerjee $H$ (2015). Effect of sulphur fertilization on yield, S uptake and quality of Indian Mustard under varied irrigation regimes. Plant Soil Environ 61: 6-10.

33. Imran \& Khan AA (2017). Canola yield and quality enhanced with sulphur fertilization. Russia Agric Sci 43(2): 113-119. 